\title{
ANALYZING THE DEIXIS OF SONG LYRICS IN ADELE ENTITLED ALL I ASK
}

\author{
Rian Abdus Salamudin ${ }^{1}$, Efransyah ${ }^{2}$ \\ IKIP Siliwangi \\ ${ }^{1}$ rianabdus@gmail.com, ${ }^{2}$ efransbae@gmail.com
}

\begin{abstract}
The title of this research is analyzing the Deixis of Song Lyrics in Adele entitled "All I Ask". The researchers used a descriptive qualitative method in this research. This research are aimed to find out the types of deixis (Personal, Spatial, and Temporal) and the most dominant deixis which found in the lyrics of Adele's song. Based on the results and discussion, the researchers concluded that all deixis which proposed by Yule are found in Adele's song lyrics. Personal deixis is mostly found in 38 occurrences dominate in this song. The words are "I, me, we, our, ours, us, and my" as the first person deixis, "you, and your" as the second person deixis, and "they and it" as the third person deixis. In the second position is spatial deixis, this, and in your eyes which found in 5 occurrences. The third position is temporal deixis, coming next, tomorrow, and last night which found in 3 occurrences.
\end{abstract}

Keywords: Deixis, Song, Lyric

\section{INTRODUCTION}

All languages do contain small sets of words, which meanings vary systematically according to whom used them, and where, and when they are used (Hurford \& Heasley, 1986:62-63). Language are used to express emotions, interactions, and inner thoughts in written communication, and both oral. Oral means the process of expressing feelings and ideas of providing the information is done orally to understand a language. It is connected to pragmatics study. (Astria et al., 2019) states that pragmatics is the study of the aspect of the relationship between language and context that are relevant to the writing grammar. One of the issues within pragmatics study is deixis. Deixis is the use of certain linguistic items to refer to entities by pointing at them linguistically instead of providing information about their type, size, colour and so on (Brown \& Miller, 2013:25) in (Wibowo \& Nailufar, 2018).

In this research, the researchers classified the deixis which proposed by Yule (1996). The researchers ware interested to study in analyzing deixis in Adele's song lyrics entitled "All I Ask" because it usually has a deep meaning that the singer or the songwriter wants to share or conveyed to the listeners. The researchers used some theories to support this research, they are follows:

\section{Deixis}

\section{Definition of deixis}

According to (Yule, 1995: 9) deixis is a technical term (from Greek) for one of the most basic things we do with utterances. It means "pointing via" language. Any linguistic form used to accomplish this pointing is called a deictic expression. Setiakawanti \& Susanti, (2019) as cited in Yulistiani \& Parmawati (2020) state that Deixis is one of pragmatics that is studied about point to something with language.Deictic word is one which takes some element of its meaning from the situation (i.e. the speaker, the addressee, the time and the place) of the utterance in which it is used (James, 1983, p. 63) in (Hutauruk, 2018). 
In summary, deixis is the word that is moving or changing depends on the speaker, place, and time that analyzed based on the context.

\section{Kinds of deixis}

The kinds of deixis based on (Yule, 1996:9) categorizes deixis into three types, spesifically person deixis, spatial deixis, and temporal deixis.

\section{a. Person deixis}

Yule (1996:9) in (Afrilian et al., 2019) states that person clearly operates on a basic three part division exemplified by pronouns, they are: a. First person (I), singular pronouns like i, myself, my, mine, and me are also belong to first person deixis. Plural pronoun like we, ourselves, us, our, and ours. b. Second person (you), person deixis are pronouns like yourselves, yourself, yours, your are also belong to second person deixis. c. Third person (she, he or it), plural third person deixis like They are also belong to third person deixis. The researchers concluded that person deixis are any expression used in pointing a person.

\section{b. Spatial deixis}

According to (Dwipayani et al., 2020) deixis of place is relation to the location of some spaces between the speaker and the listener. spatial deixis can be divided into two they are proximal (close to the speaker), and distal (which is sometimes close to the addressee). Points out that spatial deictic word indicates location in space relative to the speaker. Usually expressed in this, these, there, here, that, and those (Cruse, 2006, p. 166) in (Nasution et al., 2018). (Astria et al., 2019) states that the form of adverb (here, there) and demonstrative pronouns (this and that). The terms of proximal and distal are also used in place deixes. The researchers concluded that spatial deixis is an expression used to indicate the location.

\section{c. Temporal deixis}

Levinson (1983, p. 62) in (Ainiyah et al., 2019) defines time deixis as reference to the time, mostly towards the adverbs of time, when an utterance is spoken. It's used to locate points or intervals on the time axis, using the moment of utterance point. The markers of temporal in deixis of time are next week, now, then, and last month. The researchers concluded that temporal deixis is an expression used to indicate the time.

\section{METHOD}

This is a research used a descriptive qualitative method. According to Ospina (2004, cited in Kuswandi \& Apsari, 2019), qualitative research as a form of systematic empirical inquiry into meaning. The instrument that the researchers used in this study are documented and library method to collect the data. In data collection, the researchers did some steps. The first, the researchers listened to the song. The second, the researchers searched the song lyrics of All I Ask by Adele on the internet. The third, the researchers analyzed the deictic words which found in song lyrics. And the last, the researchers categorized the data into the types of deixis based on the choosen theory.

\section{RESULTS AND DISCUSSION}

\section{Results}

After conducting the research, the researchers found some data. They are as follow: 
Table 1

Deixis frequency in song lyrics in adele entitled All I Ask.

\begin{tabular}{|c|c|c|c|c|}
\hline No & Type of deixis & Deictical word & Quantity & Total \\
\hline \multirow[t]{10}{*}{1} & \multirow{10}{*}{ Personal } & I & 12 & \multirow[t]{10}{*}{38} \\
\hline & & You & 4 & \\
\hline & & $\mathrm{We}$ & 4 & \\
\hline & & They & 2 & \\
\hline & & My & 3 & \\
\hline & & Your & 2 & \\
\hline & & $\mathrm{Me}$ & 7 & \\
\hline & & Our & 1 & \\
\hline & & Us & 1 & \\
\hline & & It & 2 & \\
\hline \multirow[t]{2}{*}{2} & \multirow[t]{2}{*}{ Spatial } & This & 4 & \multirow[t]{2}{*}{5} \\
\hline & & In your eyes & 1 & \\
\hline \multirow[t]{3}{*}{3} & \multirow[t]{3}{*}{ Temporal } & Tomorrow & 1 & \multirow[t]{3}{*}{3} \\
\hline & & Last night & 1 & \\
\hline & & Coming next & 1 & \\
\hline
\end{tabular}

\section{Discussion}

After the researchers classified the result of collecting data above, they analyzed those data as follow:

\section{Data 1}

\section{Personal deixis}

The researchers found nine words that belong to personal deixis from the table above, six words as the first person deixis are i, me, my, our, we and us, and two words as the second person deixis are you, and your, and two word as the third person deixis are they, and it. They are taken from those the song lyrics as follows:

\section{I don't need your honesty,}

They've all been said before.

The researchers found two kinds of first person deixis is "I", one kind of second person deixis is "Your", and one kind of third person deixis is "They". First person deixis, "I", refers to the speaker or the singer as the subject. "Your", second person deixis, refers to the someone. "They", refers to people which is not exist in this song lyric.

\section{Data 2}

\section{Spatial deixis}

The researchers found two words that belong to spatial deixis from the table above, This, and In your eyes. They are taken from those the song lyrics as follows:

If this is my last night with you

It's already in your eyes.

The researchers found two kinds of spatial deixis "This", and "in your eyes" refers to the singer or the speaker as near place with speaker.

\section{Data 3}

\section{Temporal deixis}


The researchers found three words that belong to temporal deixis from the table above, three words as temporal deixis (last night, tomorrow, and coming next). They are taken from those the song lyrics as follows:

Like we're not scared of what is coming next,

I know there is no tomorrow,

If this is my last night with you.

The researcher found three kinds of temporal deixis "last night, tomorrow, and coming next" refers to the singer or the speaker as the time.

\section{CONCLUSION}

Based on the results and discussion above, the researchers concluded that all deixis which proposed by Yule are found in Adele's song lyrics. Personal deixis is mostly found in 38 occurrences dominate in this song. The words are "I, me, we, our, ours, us, and my" as the first person deixis, "you, and your" as the second person deixis, and "they and it" as the third person deixis. In the second position is spatial deixis, this, and in your eyes which found in 5 occurrences. The third position is temporal deixis, coming next, tomorrow, and last night which found in 3 occurrences.

\section{ACKNOWLEDGMENTS}

All praise to Allah for helping this research. The author would like to thank to supervisor especially Mr. Efransyah S.Pd, M.Hum who helped and guide the establish of this article to fulfilment of the requisites for the Sarjana Pendidikan Degree. The author also thank to the lecturers, especially who managed the journals until this journal can be published. And the last, thank to my parents, for all support especially for financial support during making this article.

\section{REFERENCES}

Afrilian, W., Rozelin, D., \& Rahmi, A. (2019). Deixis in Judith McNaught's Night Whispers Novel. Indonesian Journal of EFL and Linguistics, 4(1), 41. https://doi.org/10.21462/ijefl.v4i1.100

Ainiyah, K., Sili, S., \& Ariani, S. (2019). Analysis of Deixis in Pitch Perfect 2 Movie. Jurnal Ilmu Budaya, 3(3), 288-302.

Astria, A., Mujiyanto, J., \& Rukmini, D. (2019). The Realization of Deixis in Students ' Writing at Sekolah Tinggi Keguruan dan Ilmu Pendidikan Muhammadiyah Pringsewu Lampung. English Education Journal, 9(4), 517-526.

Dwipayani, N. M., Subagia, I. K., \& Gede Suarjaya, A. A. (2020). Deixis Found in Movie Script Sing. KULTURISTIK: Jurnal Bahasa Dan Budaya, 4(1), 44. https://doi.org/10.22225/kulturistik.4.1.1574

Hurford, JR \& Heasly, B. (1984). Semantics: A Course Book. UK: Cambridge University Press. Hutauruk, B. S. (2018). Stylistic Analysis Of Deictic Expressions Used on EFL Written Essay Grade III at English Department at FKIP UHN Pematangsiantar. Journal of English Language and Culture, 8(2), 98-110. https://doi.org/10.30813/jelc.v8i2.1094

Kuswandi, M., \& Apsari, Y. (2019). An Analysis Of Pauses, Overlaps And Backchannels In Conversation In Vlog By Nessie Judge. Project (Professional Journal Of English Education), 2(3), 282-291

Nasution, D. R. A., Setiadi, G., \& Ilza, S. S. (2018). Deixis Analysis in the Song Lyrics of Ed Sheeran's Divide Album. Journal of 2nd English Language and Literature International 
Conference (ELLiC) Proceedings, 2, 376-382.

Wibowo, A. I., \& Nailufar, N. (2018). Deixis and Its Context Used in "Girl in Pieces" Novel by Kathleen Glasglow. Wanastra: Jurnal Bahasa Dan Sastra, 10(2), 73-84. https://doi.org/10.31294/w.v10i2.4125

Yulistiani, D., \& Parmawati, A. (2020). An Analysis of Deictic Expression in The Article Selected From Detiknews About Krakatoa's Mount Disaster 2018. PROJECT (Professional Journal of English Education), 3(6), 751-756. http://dx.doi.org/10.22460/project.v3i6.p751-756 